УдК 616.831-009.7-036.12:616.857-036.12]-078.088.7

https://doi.org/10.51523/2708-6011.2021-18-2-21

\title{
Molecular genetic markers of the risk of tension-type headache and migraine chronization development
}

\author{
(C) Svetlana A. Kostiuk ${ }^{1}$, Olga S. Poluyan ${ }^{1}$, \\ Maxim V. Simirski², Irina P. Marjenko ${ }^{3}$ \\ ${ }^{1}$ Belarusian Medical Academy of Post-Graduate Education, Minsk, Belarus \\ ${ }^{2}$ Belarusian State Medical University, Minsk, Belarus \\ ${ }^{3}$ Republican Research and Clinical Center of Neurology and Neurosurgery, Minsk, Belarus
}

\begin{abstract}
Objective: to identify the molecular genetic criteria of the risk of tension-type headache and migraine chronization development.

Materials and methods. The detection of the results for the determination of allelic variants was carried out by means of horizontal electrophoresis using a molecular weight marker. The determination of the genotypes of the polymorphic variants of genes was carried out using high resolution melting PCR analysis.

Results. Based on the performed molecular genetic studies, it has been established that the statistically significant $(\mathrm{p}<0.05)$ risk factors of tension-type headache chronization are: the identification of the A-allele and AA-genotype of the DBH3 polymorphism of the dopamine-beta-hydroxylase gene $D B H$, as well as the identification of the G-allele and the GG-genotype of the Intron3SNP polymorphism of the preprotachykinin gene TAC1. It has been found that the statistically significant $(\mathrm{p}<0.05)$ risk factors of migraine chronization are: the identification of the A-allele, GA- and AA-genotypes of the G29A polymorphism of the serotonin transporter gene SLC6A4, as well as the identification of the G-allele and the GG-genotype of the rs7793277 polymorphism of the preprotachykinin gene TAC1.

Conclusion. The detection of these polymorphisms of the dopamine and preprotachykinin genes in the blood serum increases the risk of tension headache chronization by 1.395-1.991 times; the risk of migraine chronization by $1.235-1.395$ times.
\end{abstract}

Key words: chronic tension-type headache, chronic migraine, serotonin, dopamine, preprotachykinin, chronization development risk.

Author contributions: Kostiuk S.A., Poluyan O.S., Simirski M.V., Marjenko I.P.: research concept and design, biological material sampling, primers and probes selection, PCR analysis conditions optimization, obtaining experimental data, statistical data processing, editing, discussing data, reviewing publications on the topic of the article, checking critical content, approving the manuscript for publication.

Conflict of interests: authors declare no conflict of interest.

Funding: study conducted without sponsorship.

For citation: Kostiuk SA, Poluyan OS, Simirski MV, Marjenko IP. Molecular genetic markers of the risk of tension-type headache and migraine chronization development. Health and Ecology Issues. 202 1;18(2):147154. (In Russ.). https://doi.org/10.51523/2708-6011.2021-18-2-21

\section{Момекумярно-генетнческие маркеры риска развития хронизацин гомовной боли напряженного типа и мигрени}

\author{
(C) С. А. Костюк ${ }^{1}$, О. С. Полуян ${ }^{1}$, М. В. Симирский ${ }^{2}$, И. П. Марьенко ${ }^{3}$ \\ ${ }^{1}$ Белорусская медииинская академия последипломного образования, г. Минск, Республика Беларусь \\ ${ }^{2}$ Белорусский государственный медииинский университет, г. Минск, Республика Беларусь \\ ${ }^{3}$ Республиканский научно-практический центр неврологии и нейрохирургии, г. Минск, Республика Беларусь
}

\section{PЕЗЮМЕ}

Цель: установить молекулярно-генетические критерии риска хронизации головной боли напряженного типа и мигрени.

материалы и методы. Детекцию результатов по определению алмельных вариантов проводими методом горизонтального электрофореза с использованием маркера молекулярных масс. Определение генотипов полиморфных вариантов генов проводили с применением метода анализа кривых плавцения продуктов ПЦР высокого разрешения. 
Резулътатъ. На основании проведенных молекулярно-генетических исследований установлено, что статистически значимыми ( $<0,05)$ достоверными факторами риска хронизации головной боли напряженного типа являются: выявление A-амлеля и AA-генотипа полиморфизма DBH3 гена дофамин-бета-гидроксилазы $D B H$, а также выявление G-аллеля и GG-генотипа полиморфизма Intron3SNP гена препротахикинина ТАC1. Установмено, что статистически значимыми (p < 0,05) достоверными факторами риска хронизации мигрени являются: выявление A-амлеля, GA- и AА-генотипов полиморфизма G29A гена транспортера серотонина SLC6A4, а также выявление G-амлеля и GG-генотипа полиморфизма rs7793277 гена препротахикинина TAC1.

Заключение. Выявление в сыворотке крови указанных полиморфизмов генов дофамина и препротахикинина увеличивает риск хронизации головной боли напряженного типа в 1,395-1,991 раза, риск хронизации мигрени — в 1,235-1,395 раза.

Кмючевые смова: хроническая головная боль напряженного типа, хроническая мигрень, серотонин, дофрамин, препротахикинин, риск развития хронизаиии.

Вк^ад авторов: Костюк С.А., Полуян О.С., Симирский М.В., Марьенко И.П.: концепция и дизайн исследования, взятие образцов биологического материала, подбор праймеров и зондов, оптимизация условий проведения ПЦР-анализа, получение экспериментальных данных, статистическая обработка данных, редактирование, обсуждение данных, обзор публикаций по теме статьи, проверка критически важного содержания, утверждение рукописи дмя публикации.

Конфмикт интересов: авторы заявцяют об отсутствии конфмикта интересов.

Источники финансирования: исследование проведено без спонсорской поддержки.

Дия цитирования: Костюк СА, Полуян ОС, Симирский МВ, Марьенко ИП. Молекулярно-генетические маркеры риска развития хронизации головной боли напряженного типа и мигрени. Проблемы здоровъя и экологии. 2021;18(2):147-154. https://doi.org/10.51523/2708-6011.2021-18-2-21

\section{Introduction}

Migraine is one of the most common forms of primary headache manifested by attacks of throbbing headache, more often by hemitype, in most cases accompanied by nausea, occasionally vomiting, poor tolerance of bright light (photophobia) and loud sounds (phonophobia). In almost one-third of patients, the attack is accompanied by transient neurological symptoms - migraine aura. The diagnostic criteria for migraines are listed in the International Classification of Headache Disorders, according to which primary, secondary forms of headache, as well as cranial neuralgia, central and primary facial pains, and other headaches are distinguished.

Primary headaches include:

- migraine, which is divided into two types: migraine without aura and migraine with aura;

- tension-type headache;

- bundle (cluster) headache and other trigeminal vegetative (autonomous) cephalgias;

- other primary headaches.

According to epidemiological research, migraines affect from 5 to $38 \%$ of the world population [1]. In 2000, migraine was included in the list of diseases that pose a significant problem for humanity, due to its widespread, significant impact on the quality of life of patients and socioeconomic consequences [3].

Despite the fact that family burden is not included in the diagnostic criteria of chronic tension-type headache and chronic migraine, the contribution of genetic factors into the determination of the pathogenesis of these diseases is very significant $[4,5]$.

The most significant evidence of the genetic origin of chronic tension-type headache and chronic migraines is provided by molecular genetic researches: the identification of the number of genes and loci on chromosomes, as well as the study of associations of candidate genes with the risk of the development of these diseases [6].

In the pathogenesis of chronic tension-type headache and chronic migraine, a significant role is played by the neurotransmitter serotonin, which, on the one hand, has a distinct effect on the cerebral vessels, on the other participates in pain impulse conduction $[7,8$, $9,10]$. Headache has a hereditary sensitivity to specific stimuli or to cyclic changes in the central nervous system, which is expressed in neurovascular reactions. Migraines appear due to a central neurochemical imbalance, which includes low serotonin levels. Abnormal neurotransmission of serotonin triggers a cascade of events which leads to headache and accompanying symptoms [11].

Dopamine is a neurotransmitter that is also involved in the regulation of blood circulation in the brain, which proves its participation in the pathological mechanisms of the occurrence of chronic tension-type headache and chronic 
migraine. A low concentration of blood plasma dopamine leads to hypersensitivity of the corresponding receptors, which is one of the pathogenetic links in the formation of the disease [12, 13, 14].

An important role in the development of chronic tension-type headache and chronic migraine is played by tachykinins, one of the largest groups of neuropeptides with the similar C-terminal sequence Phe-X-Gly-Leu-MetNH2 [15]. The genes encoding the precursors of tachykinins are called preprotachykinins. Neurokinin A and substance P, encoded by the human TAC1 gene, participate in sensory neurotransmission [16] and regulation of the central process - the pain threshold [17].

\section{Objective}

To identify the molecular genetic risk factors for the development of chronic tensiontype headache and migraine on the basis of the conducted molecular genetic study.

\section{Materials and methods}

The subjects of the study were patients with chronic tension-type headache and chronic migraine. The venous blood of 40 patients with the confirmed diagnosis of "chronic tensiontype headache" (group 1) and 72 patients with the confirmed diagnosis of "chronic migraine" (group 2) who were undergoing inpatient treatment in the state institution "Republican Research and Clinical Center of Neurology and Neurosurgery" was used as the biological material for the study. The control group consisted of 30 practically healthy individuals. The age of the patients at the time of examination was Me (25/75 (percentile): for group $1-40.50(31.00 / 46.00)$ years, for group $2-40.00(31.00 / 46.00)$ years, for the control group - $41.00(32.75 / 49.50)$ years. The gender distribution in the groups was as follows: in group 1, the female/male ratio was $82.50 \%(\mathrm{n}=33) / 18.50 \%(\mathrm{n}=7)$, in group 2 $81.94 \%(n=59) / 18.06 \%(n=13)$, in the control group - $80.00 \%(n=24) / 20.00 \%(n=6)$. As a result, the groups were comparable by gender and age.

DNA isolation from the biological material was performed by means of DNA sorption on the membrane surface of a special column (a set of reagents “ArtDNA MiniSpin” (“ArtBioTech”, BY).

To determine the concentration and degree of purity of the isolated DNA, we performed spectrophotometric studies (NanoDrop 1000, Thermoscientific, USA), at the same time deter- mining the absorption ratio at the wavelengths of 260 and $280 \mathrm{~nm}$ (A260/280).

The following targets were selected for the design of specific oligonucleotide primers: the gene encoding the serotonin transporter protein (SLC6A4) (GenBank ID 6532), the gene encoding dopamine-beta-hydroxylase $(D B H)$ (GenBank ID 1621), and the gene encoding preprotachykinin (TAC1) (GenBank ID 6863).

The following pairs of specific oligonucleotide primers were used to identify 5-HTTLPR and G29A polymorphisms of the serotonin transporter gene SLC6A4:

\section{S-1-F-5'-GGCGTTGCCGCTCTGAATGC-3'}

S - 1 - R - 5 ' - G A G G G A C T G A G C T G G A CAACC-3' (for 5-HTTLPR detection);

S-2-F-5'-CTCACCAGCGTCACCACA-3'

S-2-R-5' - CTCACATCAACCCTGCTTAGG-3' (for G29A detection).

The following pairs of specific oligonucleotide primers were used to identify the polymorphisms of DBH2 and DBH3 of the dopamine-beta-hydroxylase $\mathrm{DBH}$ gene:

D-2 - F- 5' - GCAAAAGTCAGGCACATG CACC-3'

D-2-R-5'-GTCAGCGAGATGGGGAGGTGGA-3' (for DBH2 detection);

D-3-F-5'-TCCTTCATGCCTGGAGCCCAGTGCTTGTCT-3'

D-3-R-5'-GACAGGAAAGGTACTATGACATTGGCACAG-3' (for DBH3 detection).

The following pairs of specific oligonucleotide primers were used to detect the rs7793277 and Intron3SNP polymorphisms of the preprotachykinin TAC1 gene:

T-1-F-5'-GCCCTCTTCCAGGTTACAGACTGT-3'

T-1-R-5'-GCGGTACACTCTCCTGACCTGTC-3' (for rs7793277 detection);

T-2-F-5'-GTGCGATGAATTCAAGGAAACGAT-3'

T-2 - R - 5' - CAAGTGCATGTGGAAGAG GATTTT-3' (for Intron3SNP detection).

The composition of the reaction mixture to detect polymorphisms in 5-HTTLPR and the G29A gene and serotonin Transporter SLC6A4: $1 \mu \mathrm{l}$ genomic DNA $(50 \mu \mathrm{g} / \mu \mathrm{l})$ and $0.4 \mu \mathrm{l}$ of each primer $(5 \mathrm{mM})$ and $0.2 \mu \mathrm{l}$ Taq polymerase $(1 \mathrm{U} \mu \mathrm{l})$, $5 \mu \mathrm{l}$ of Master-Mix, of $13.0 \mu \mathrm{LEPC}$; the final volume is $20 \mu \mathrm{l}$. The thermal cycling conditions are: $95{ }^{\circ} \mathrm{C} 3 \mathrm{~min}$ (hot start); 38 cycles $95{ }^{\circ} \mathrm{C} 45 \mathrm{~s}$ (denaturation), $63{ }^{\circ} \mathrm{C} 60 \mathrm{~s}$ (annealing), $72{ }^{\circ} \mathrm{C} 60 \mathrm{~s}$ (elongation); $72{ }^{\circ} \mathrm{C} 7 \mathrm{~min}$.

The composition of the reaction mixture to detect polymorphisms of DBH2 and DBH3 gene and the dopamine-beta-hydroxylase $D B H: 1 \mu 1$ genomic DNA $(20 \mu \mathrm{g} / \mu \mathrm{l})$ and $0.4 \mu \mathrm{l}$ of each primer 
$(5 \mathrm{~mm})$ and $0.2 \mu 1$ Taq polymerase $(5 \mathrm{U} / \mu \mathrm{l}), 5 \mu \mathrm{l}$ Master-Mix, of $13.0 \mu 1 \mathrm{DEPC}$; the final volume is $20 \mu 1$. The thermal cycling conditions are: $94^{\circ} \mathrm{C}$ 5 min (hot start); 40 cycles $-94{ }^{\circ} \mathrm{C} 30 \mathrm{~s}$ (denaturation), $60{ }^{\circ} \mathrm{C} 30 \mathrm{~s}$ (annealing), $72{ }^{\circ} \mathrm{C}$ $30 \mathrm{~s}$ (elongation); $72{ }^{\circ} \mathrm{C} 2 \mathrm{~min}$.

The composition of the reaction mixture for the detection of the polymorphisms rs7793277 and Intron3SNP gene preprotachykinin TAC1: $1 \mu \mathrm{l}$ genomic DNA $(50 \mu \mathrm{g} / \mu \mathrm{l})$ and $0.4 \mu \mathrm{l}$ of each primer $(5 \mathrm{mM})$ and $0.2 \mu \mathrm{l}$ Taq polymerase $(1 \mathrm{U} / \mu \mathrm{l})$, $5 \mu 1$ of Master-Mix, of $13.0 \mu \mathrm{LEPC}$; the final volume is $20 \mu 1$. The thermal cycling conditions are: $95^{\circ} \mathrm{C} 5 \mathrm{~min}$ (hot start); 40 cycles $-95^{\circ} \mathrm{C} 45 \mathrm{~s}$ (denaturation), $60{ }^{\circ} \mathrm{C} 30 \mathrm{~s}$ (annealing), $72{ }^{\circ} \mathrm{C}$ $30 \mathrm{~s}$ (elongation); $72{ }^{\circ} \mathrm{C} 5 \mathrm{~min}$.

The detection of the allelic variants was performed by horizontal electrophoresis using a molecular weight marker.

The determination of the genotypes (homoand heterozygous spectra) of the polymorphic gene variants was performed by means of the method of high resolution PCR product melting curves (high resolution melting analysis HRM-analysis) using the intercalating dye EvaGreen. The tubes were filled with: $10 \mu \mathrm{l}$ SsoFast EvaGreen, $2 \mu 1$ direct primer, $2 \mu 1$ reverse primer, $6 \mu 1$ of isolated DNA. The total volume of the sample was $20 \mu 1$. The samples were placed in an amplifier. The device was programmed according to the following program: $98{ }^{\circ} \mathrm{C} 3 \mathrm{~min}$ (activation of the enzyme); 40 cycles $98{ }^{\circ} \mathrm{C} 5$ $\mathrm{s}$ (denaturation), $55^{\circ} \mathrm{C} 5 \mathrm{~s}$ (annealing/elonga- tion). The removal of melting curves, which is a temperature increase from $75^{\circ}$ to $95{ }^{\circ} \mathrm{C}$ with registration of the fluorescence intensity, was carried out in increments of $0.5^{\circ} \mathrm{C}(5 \mathrm{~s}$ per step).

All quantitative data had a nonparametric distribution (the normality test was performed using the Kolmogorov-Smirnov criterion) and are presented as median and quartile values (Me (Q25/75)). Absolute and relative (\%) indicators were used to characterize the frequency of the studied features. A $95 \%$ confidence interval (CI) was determined for the relative indicators. To determine the degree of association of the studied factors with the risk of developing the disease, the criterion $\mathrm{x}^{2}$ Pearson was used. The critical significance level for testing statistical hypotheses is assumed to be at $\mathrm{p}<0.05$. To compare the studied groups by the frequency of the detection of the risk factors for the disease development, we used the calculation of the odds ratio with the data being compiled in a $2 \times 2$ table.

\section{Results and discussion}

The recording of the data of the conducted molecular genetic studies on the distribution of the allelic variants, as well as on the determination of the genotypic profile of 5-HTTLPR and G29A gene of the serotonin Transporter SLC6A4 was done with the account of the study groups (table 1).

Table 1. Distribution of the allelic variants and genotypes of the serotonin transporter gene SLC6A4 depending on the study group

\begin{tabular}{|c|c|c|c|c|c|c|c|}
\hline \multirow{2}{*}{ Polymorphism } & \multirow{2}{*}{ Allele/ Genotype } & \multicolumn{2}{|c|}{ Group $1(n=40)$} & \multicolumn{2}{|c|}{ Group $2(\mathrm{n}=72)$} & \multicolumn{2}{|c|}{ Control $(\mathrm{n}=30)$} \\
\hline & & $\mathrm{n}$ & $\%$ & $\mathrm{n}$ & $\%$ & $\mathrm{n}$ & $\%$ \\
\hline \multirow{5}{*}{ 5-HTTLPR } & $\mathrm{L}$ & 52 & 65.00 & 106 & 73.61 & 42 & 70.00 \\
\hline & $\mathrm{S}$ & 28 & 35.00 & 38 & 26.39 & 18 & 30.00 \\
\hline & LL & 19 & 47.50 & 42 & 58.33 & 15 & 50.00 \\
\hline & SS & 7 & 17.50 & 8 & 11.11 & 3 & 10.00 \\
\hline & LS & 14 & 35.00 & 22 & 30.56 & 12 & 40.00 \\
\hline \multirow{5}{*}{ G29A } & G & 75 & 93.75 & 117 & 81.25 & 58 & 96.67 \\
\hline & A & 5 & 6.25 & 27 & 18.75 & 2 & 3.33 \\
\hline & GG & 35 & 87.50 & 53 & 73.61 & 28 & 93.33 \\
\hline & AA & - & - & 8 & 11.11 & - & - \\
\hline & GA & 5 & 12.50 & 11 & 15.28 & 2 & 6.67 \\
\hline
\end{tabular}

When analyzing the genetic structure of the patients with chronic tension-type headache and chronic migraine, the distribution of genotypes characteristic of the Caucasian population was revealed: the frequency of the occurrence of the S-allele of 5-HTTLPR polymorphism is 0.32 , the 
frequency of genotypes corresponds to LL-0.47, SS - 0.15, LS - 0.38. According to our data, the genotypic profile of the patients with chronic tension-type headache and chronic migraine was characterized by the following indicators: LL -0.47 and 0.58 ; SS - 0.18 and 0.11 ; LS 0.35 and 0.31 , respectively. The frequency of the S-allele was 0.5 and 0.26 , respectively. When analyzing the allelic and genotypic profiles of the patients in the control group, there were no statistically significant differences $(p>0.05)$ in the distribution compared to the main group of patients, as well as compared with the population data.

Within the course of the molecular genetic studies aimed at the determination of the alleles and genotypes of the G29A polymorphism, it was found that the detection of A-alleles (and, respectively, the genotype of $\mathrm{AA}$ and $\mathrm{GA}$ ) is typical for patients with chronic migraine: the frequency of the occurrence of the A-allele in group 1 was 0.06 , in group $2-0.19$, in the control group - 0.03. The genotype profile was characterized by the following distribution: in group 1, GG - 0.88, GA - 0.12; in group 2, GG - 0.74, GA - 0.15; in the control group, $\mathrm{GG}-0.93, \mathrm{GA}-0.07$. In group 2 of the patients with chronic migraine, the genotype profile was characterized by the presence of the AA genotype, which was detected in 8 patients (the frequency of the occurrence of AA was 0.11). Based on this fact, we suggested that there was a possible influence of the A-allele and, respectively, the AA and GA genotypes polymorphisms of the G29A polymorphism on the risk of developing chronic migraine.
The analysis of the significance of the differences in the frequency of the occurrence of signs was evaluated using the $\times 2$ criterion in the conjugacy table $2 \times 2$. The odds ratio of the development of chronic migraine in the detection of A-allele amounted to $\mathrm{OR}=1.393$ (lower-upper boundary of the $95 \%$ CI 1.206-1.608), $\mathrm{p}<0.05$; in identifying the GGgenotype, the odds ratio of the development of disease chronicity was OR $=1.235$ (lowerupper boundary of the $95 \%$ CI 0.941-1.619), $\mathrm{p}<0.05$; the identification of the AA genotype is the absolute criterion of the risk of developing chronic migraine.

The Yates-corrected $\times 2$ criterion was 7.039 for the A-allele 7.039 at $\mathrm{p}<0.05$, which indicates a statistically reliable significance of differences in outcomes depending on exposure to the risk factor. The odds ratio for the development of chronic migraine amounted to 6.692 (lower-upper boundary of the $95 \% \mathrm{CI}$ of 1.538-29.119), $\mathrm{p}<0.05$.

Thus, the laboratory criterion for the risk of developing chronic migraine is the detection of the A-allele, as well as GA- and AA-genotypes of the G29A polymorphism of the SLC6A4 serotonin transporter gene.

The recording of the data of the conducted molecular genetic studies on the distribution of the allelic variants, as well as on the determination of the genotypic profile of DBH2 and DBH3 gene of dopamine-beta-hydroxylase $D B H$ was done with the account of the study groups (table 2).

Table 2. Distribution of the allelic variants and genotypes of dopamine-beta-hydroxylase $\mathrm{DBH}$ gene depending on the study group

\begin{tabular}{|c|c|c|c|c|c|c|c|}
\hline \multirow{2}{*}{ Polymorphism } & \multirow{2}{*}{ Allele/ Genotype } & \multicolumn{2}{|c|}{ Group $1(\mathrm{n}=40)$} & \multicolumn{2}{|c|}{ Group $2(\mathrm{n}=72)$} & \multicolumn{2}{|c|}{ Control $(\mathrm{n}=30)$} \\
\hline & & $\mathrm{n}$ & $\%$ & $\mathrm{n}$ & $\%$ & $\mathrm{n}$ & $\%$ \\
\hline \multirow{5}{*}{ DBH2 } & Del & 39 & 48.75 & 60 & 41.67 & 26 & 43.33 \\
\hline & Ins & 41 & 51.25 & 84 & 58.33 & 34 & 56.67 \\
\hline & $\mathrm{del} / \mathrm{del}$ & 10 & 25.00 & 18 & 25.00 & 5 & 16.67 \\
\hline & ins/ins & 11 & 27.50 & 30 & 41.67 & 9 & 30.00 \\
\hline & del/ins & 19 & 47.50 & 24 & 33.33 & 16 & 53.33 \\
\hline \multirow{5}{*}{ DBH3 } & G & 25 & 31.25 & 69 & 47.92 & 31 & 51.67 \\
\hline & A & 55 & 68.75 & 75 & 52.08 & 29 & 48.33 \\
\hline & GG & 7 & 17.50 & 15 & 20.83 & 14 & 23.33 \\
\hline & AA & 22 & 55.00 & 18 & 25.00 & 12 & 20.00 \\
\hline & GA & 11 & 27.50 & 39 & 54.17 & 34 & 56.67 \\
\hline
\end{tabular}

The frequency of alleles and genotypes as per DBH2 polymorphic loci did not differ from the average population, and no deviations from the Hardy-Weinberg equilibrium were detected. 
The frequency rates of Del-allele polymorphism DBH2 in the groups of patients with chronic headache of the tension-type and chronic migraine were 0.49 and 0.42 , the detection rate of the Ins-allele -0.51 and 0.58 ; the rate of the detection of genotypes in the studied groups was $-\mathrm{del} / \mathrm{del}-0.25$ and 0.25 , ins/ ins 0.27 and 0.42 , del/ins -0.48 and 0.33 . In the control group, the detection rate of Del- and Ins-alleles was 0.43 and 0.57 , respectively; the genotype frequency was $-\mathrm{del} / \mathrm{del}-0.17$, ins / ins -0.53 , and del/ins -0.30 .

Based on the performed studies, we found that the frequency of the occurrence of the A-allele DBH3 in the biological material of the patients with chronic tension-type headache was 0.68 as compared to 0.52 in the group of the patients with chronic migraine and 0.48 in the control group. In addition, an increase in the frequency of the detection of AA-genotype DBH3 in this group is noteworthy: 0.55 against 0.25 in group 2 and 0.20 in the control group. Based on this fact, we suggested there was a possible influence of the A-allele and AAgenotype of DBH3 polymorphism on the risk of developing chronic tension-type headache.

The analysis of the significance of differences in the frequency of the occurrence of signs was evaluated using the $\times 2$ criterion in the conjugacy table $2 \times 2$. The odds ratio of the development of chronic tension-type headache when detecting the A-allele was OR $=1.467$ (lower-upper bound of $95 \%$ CI 1.054-2.041), $\mathrm{p}<0.05$; with the AA genotype, the odds ratio was $\mathrm{OR}=1.823$ (lower-upper bound of $95 \% \mathrm{CI}$ 1.230-2.733), $\mathrm{p}<0.05$.

The Yates-corrected $\times 2$ criterion was 5.135 for the A-allele at $\mathrm{p}<0.05$, which indicates a statistically significant difference in outcomes depending on exposure to the risk factor. The ratio of chances for the development of chronic tension-type headache with the detection of the A-allele was 2.325 (lower-upper bound of $95 \%$ CI 1.176-4.702) at $\mathrm{p}<0.05$; with the detection of the AA genotype - 4.889 (lower-upper bound of $95 \%$ CI 1.644-14.543) at $\mathrm{p}<0.05$.

Thus, the laboratory risk criterion for the development of chronic tension-type headache is the detection of the A-allele, as well as the AA-genotype of the DBH3 polymorphism gene of dopamine-beta-hydroxylase $D B H$.

The recording of the data of the conducted molecular-genetic studies on the distribution of the allelic variants, as well as on the determination of the genotypic profile of rs7793277 and Intron3SNP of the protachykinin TAC1 gene was done with the account of the study groups (table 3 ).

Table 3. Distribution of the allelic variants and genotypes of the preprotahikinin gene TAC1 depending on the study group

\begin{tabular}{|c|c|c|c|c|c|c|c|}
\hline \multirow{2}{*}{ Polymorphism } & \multirow{2}{*}{$\begin{array}{l}\text { Allele/ Geno- } \\
\text { type }\end{array}$} & \multicolumn{2}{|c|}{ Group $1(n=40)$} & \multicolumn{2}{|c|}{ Group $2(\mathrm{n}=72)$} & \multicolumn{2}{|c|}{ Control $(n=30)$} \\
\hline & & $\mathrm{n}$ & $\%$ & $\mathrm{n}$ & $\%$ & $\mathrm{n}$ & $\%$ \\
\hline \multirow{5}{*}{ rs7793277 } & $G$ & 56 & 70.00 & 122 & 84.72 & 42 & 70.00 \\
\hline & $\mathrm{C}$ & 24 & 30.00 & 22 & 15.28 & 18 & 30.00 \\
\hline & GG & 27 & 67.50 & 53 & 73.61 & 15 & 50.00 \\
\hline & $\mathrm{CC}$ & 11 & 27.50 & 3 & 4.17 & 3 & 10.00 \\
\hline & GC & 2 & 5.00 & 16 & 22.22 & 12 & 40.00 \\
\hline \multirow{5}{*}{ Intron3SNP } & $\mathrm{G}$ & 70 & 87.50 & 94 & 65.28 & 39 & 65.00 \\
\hline & $\mathrm{C}$ & 10 & 12.50 & 50 & 34.72 & 21 & 35.00 \\
\hline & GG & 32 & 80.00 & 30 & 41.67 & 13 & 43.33 \\
\hline & $\mathrm{CC}$ & 2 & 5.00 & 8 & 11.11 & 4 & 13.34 \\
\hline & GC & 6 & 15.00 & 34 & 47.22 & 13 & 43.33 \\
\hline
\end{tabular}

On the basis of the conducted molecular genetic studies, we found an increase in the frequency of the detection of the rs7793277 G-allele in the biological material of the patients with chronic migraine - it was 0.85 , while in the group of the patients with chronic tensiontype headache and in the control group - 0.70 .
A similar trend was found for the GG genotype rs7793277 — in the group of the patients with chronic migraine, it was 0.74 , while in the group of the patients with chronic headache and the control group, it was 0.68 and 0.50 , respectively. Based on the obtained data, we suggested there was a possible influence of 
the G-allele and GG-genotype on the risk of developing chronic migraine.

The analysis of the significance of differences in the frequency of the occurrence of signs was evaluated using the $\times 2$ criterion in the conjugacy table $2 \times 2$. The odds ratio of developing chronic migraine with the detection of the G-allele was OR $=1.353$ (lower-upper limits of $95 \%$ CI 1.008-1.815), p < 0.05; with the detection of the GG-genotype, the odds ratio of developing chronic disease was OR=1.395 (lowerupper limits of $95 \%$ CI 1.008-1.929), p < 0.05 .

The Yates-adjusted $\times 2$ criterion was 4.927 for the G-allele at $\mathrm{p}<0.05$, which indicates statistically significant differences in outcomes depending on the exposure to the risk factor. The odds ratio for the development of chronic migraine in the detection of the G-allele was 2.377 (lower-upper bounds $95 \%$ CI 1.164 $4.857)$ at $\mathrm{p}<0.05$; in the detection of the GGgenotype - 2.789 (lower-upper bounds $95 \%$ CI 1.149-6.773), $\mathrm{p}<0.05$.

Thus, the laboratory criterion for the risk of developing chronic migraine is the identification of the G-allele, as well as the GG-genotype of the rs7793277 polymorphism of the TAC1 preprotachikinin gene.

In the biological material of the patients with chronic tension-type headache, a statistically significant increase was revealed in the detection rate of G-allele Intron3SNP 0.88 against 0.65 in chronic migraine and in the control group, respectively; as well as an increase in the detection rate of GG-genotype Intron3SNP -0.80 with chronic tension-type headache, 0.42 and 0.43 in chronic migraine and control group, respectively. Based on the obtained data, we suggested there was a possible influence of the G-allele and GGgenotype on the risk of developing chronic tension-type headache.

The analysis of the significance of differences in the frequency of the occurrence of signs was evaluated using the $\times 2$ criterion in the $2 \times 2$ conjugacy table. The odds ratio of the development of chronic tension-type headache whendetecting the G-allelewas OR=1.991 (lowerupper limits of $95 \%$ CI 1.008-1.815), p < 0.05; when detecting the GG-genotype, the odds ratio of developing chronic disease was $\mathrm{R}=1.395$ (lower-upper limits of $95 \%$ CI 1.008-1.929), $\mathrm{p}<0.05$.

The Yates-adjusted $\times 2$ criterion was 4.927 for the G-allele at $\mathrm{p}<0.05$, which indicates statistically significant differences in outcomes depending on the exposure to the risk factor. The odds ratio for the development of chronic tension-type headache when detecting the G-allele was 1.991 (lower-upper bounds $95 \%$ CI 1.173-3.379) at $\mathrm{p}<0.05$; when detecting the GG-genotype-2.222 (lower-upper bounds 95\% CI 1.218-4.053) at $\mathrm{p}<0.05$.

Thus, the laboratory criterion for the risk of developing chronic tension-type headache is the identification of the G-allele, as well as the GG-genotype of the Intron3SNP polymorphism of the TAC1 preprotachikinin gene.

\section{Conclusions}

The molecular genetic risk factors for the development of chronic tension-type headache have been identified: the detection of the A-allele and AA-genotype of the DBH3 polymorphism of the dopamine-beta-hydroxylase $D B H$ gene increases the probability of developing chronic disease by 1.467 and 1.823 times, respectively; the identification of the G-allele and GG-genotype of the gene polymorphism Intron3SNP preprotachykinin TAC1 increases the likelihood of the chronic disease by 1.991 and 1.395 times, respectively.

The molecular genetic risk factors for the development of chronic migraine: A-allele and GA-genotype of the G29A polymorphism of the serotonin transporter gene SLC6A4 increases the likelihood of the development of the chronic disease by 1.393 and 1.235 times respectively, and the detection of AA-genotype is an absolute risk factor for the development of the chronic diseases; the identification of the G-allele and GG-genotype of the gene polymorphism rs7793277 preprotachykinin TAC1 increases the likelihood of developing chronic diseases by 1.353 and 1.395 times, respectively.

\section{References}

1. Olesen J, Dodick DW, Ducros A, Evers S, First MB, Goadsby PJ, et al. The International Classification of Headache Disorders, 3rd edition (ICHD-3). Cephalalgia. 2018;38(1). https://doi.org/10.1177/0333102417738202

2. Albers L, Straube A, Landgraf M, Filippopulos F, Heinen F, von Kries R. Migraine and tension type headache in adolescents at grammar school in Germany - burden of disease and health care utilization. I Headache Pain 2015;16:52. https://doi.org/10.1186/s10194-015-0534-4 3. Menken M, Munsat TL, Toole JF. The global burden of disease study. Implications for neurology. Arch. Neurol. 2000;57(3):418-420.

4. Merikangas KL. Genetics of migraine and other headache. Curr. Opin. Neurol. 1996;9(2):202-205. https:// doi.org/10.1097/00019052-199606000-00008 
5. Russel MB, Olesen J. Increased familial risk and evidence of genetic factor in migraine. BMJ Clinical Research. 1995;311(7004):541-544. https://doi. org/10.1136/bmj.311.7004.541

6. Vries B, Frants RR, Ferrari MD, van den Maagdenberg AM. Molecular genetics of migraine. Hum. Genet. 2009;126(1):115-132. https://doi.org/10.1007/ s00439-009-0684-Z

7. Borroni B, Brambilla C, Liberini P, Rao R, Archetti S, Gipponi S, et al. Functional serotonin 5-HTTLPR polymorphism is a risk factor for migraine with aura. J. Headache Pain. 2005;6:182-184. https://doi. org/10.1007/s10194-005-0179-9

8. Di Giacomo V, Ferrante C, Ronci M, Ronci M, Di Valerio V, Rapino M, et al. Multiple pharmacological and toxicological investigations on Tanacetum parthenium and Salix alba extracts: Focus on potential application as antimigraine agents. Food Chem Toxicol. 2019;133:110783. https://doi.org/10.1016/i.fct.2019.110783

9. Hamel E. Serotonin and migraine: biology and clinical implications. Cephalalgia. 2007;27(11):1293-300. https://doi.org/10.1111/j.1468-2982.2007.01476.x

10. Gellynck E, Heyninck K, Andressen KW, Haegeman G, Levy FO, Vanhoenacker P et al. The serotonin 5-HT7 receptors: two decades of research. Exp Brain Res. 2013;230(4):555-568. https://doi.org/10.1007/s00221013-3694-y

11. Hannon E, Weedon M, Bray N, O'Donovan M, Mill J. Pleiotropic Effects of Trait-Associated Genetic Variation on DNA Methylation: Utility for Refining GWAS

\section{Information about authors}

Svetlana A. Kostiuk, DMedSc, Professor, Chief Researcher at the Science-Research Laboratory, Belarusian Medical Academy of Postgraduate Education; ORCID: https://orcid.org/0000-0002-3252-2626; e-mail: s.kostiuk@mail.ru

Olga S. Poluyan, PhD (Biol), Leading Researcher at the Science-Research Laboratory, Belarusian Medical Academy of Postgraduate Education; ORCID: https:// orcid.org/0000-0001-7130-2776; e-mail: olga.poluyan@ mail.ru

Maxim V. Simirski, student, Belarusian State Medical University; ORCID: https://orcid.org/0000-00031044-5401; e-mail: simirski@mail.ru

Irina P. Marjenko, PhD (Med), Leading Researcher at the Science-Research Laboratory of the Neurological Department, Republican Research and Clinical Center of Neurology and Neurosurgery; ORCID: https://orcid. org/0000-0001-6851-1016; e-mail: iramaryenko@gmail. com
Loci. Am J Hum Genet. 2017;100(6):954-959. https://doi. org/10.1016/j.ajhg.2017.04.013

12. Cherchi A, Stochino E, Piccardi MP, Zompo M. Role of dopaminergic system in migraine. $J$ Headache Pain. 2001;2(1):47-49. https://doi.org/10.1007/ s101940170009

13. Sicuteri F. Dopamine, the second putative protagonist in headache. Headache. 1977;17(3):129131. hed1703129.x https://doi.org/10.1111/j.1526-4610.1977.

14. Mascia A, Afra J, Schoenen J. Dopamine and migraine: a review of pharmacological, biochemical, neurophysiological, and therapeutic data. Cephalalgia 1998;18(4):174-182. https://doi.org/10.1046/j.14682982.1998.1804174.x

15. Pennefather JN, Lecci A, Candenas ML, Patak E, Pinto F, Maggi CA. Tachykinins and tachykinin receptors: a growing family. Life Sci. 2004;74:1445-1463. https://doi. org/10.1016/j.lfs.2003.09.039

16. Kostyk SK, Kowall NW, Hauser SL. Substance P immunoreactive astrocytes are present in multiple sclerosis plaques. Brain Res. 1989;504(2):284-288. https://doi. org/10.1016/0006-8993(89)91369-3

17. Palma C, Minghetti L, Astolfi M, Ambrosini E, Silberstein FC, Manzini S, et al. Functional characterization of substance $\mathrm{P}$ receptors on culture human spinal chord astrocytes; synergism of substance $\mathrm{P}$ with cytokines in inducing interleukin- 6 and prostaglandin-E2 production. Glia. 1997;21(2):183-193. https://doi.org/10.1002/ (sici) 1098-1136(199710)21:2<183::aid-glia2>3.0.co;2-8

\section{/ Информация об авторах}

Костюк Светьана Андреевна, д.м.н., профессор, главный научный сотрудник Научно-исследовательской маборатории, ГУО "Беморусская медицинская академия последипломного образования"; ORCID: https://orcid. org/0000-0002-3252-2626; e-mail: s.kostiuk@mail.ru

Похуян Омьга Сергеевна, к.б.н., ведущий научный сотрудник Научно-исследовательской маборатории, ГУО "Беморусская медицинская академия последипломного образования"; ORCID: https://orcid.org/0000-00017130-2776; e-mail: olga.poluyan@mail.ru

Симирский Максим Викторович, студент УО "Беморусский государственный медицинский университет"; ORCID: https://orcid.org/0000-00031044-5401; e-mail: simirski@mail.ru

Марьенко Ирина Павцовна, к.м.н., ведущий научный сотрудник неврологического отдела, ГУ "Республиканский научно-практический центр неврологии и нейрохирургии"; ORCID: https://orcid. org/0000-0001-6851-1016; e-mail: iramaryenko@gmail. com

\section{Corresponding author / Автор, ответственный за переписку}

Svetlana A. Kostiuk

e-mail: s.kostiuk@mail.ru
Костюк Светмана Андреена

e-mail: s.kostiuk@mail.ru 